\title{
Den grenseoverskridende reindriften og beiterettighetene
}

Av professor dr.juris Øyvind Ravna

Den samiske reindriften er basert på reinens naturlige vandringer mellom vinterens lavbeiter i innlandet og sommerens grøntbeiter ved kysten. Etter at landegrensen mellom Norge og Sverige ble fastlagt i 1751, har mange samer måttet krysse statsgrensen med sine dyr for å opprettholde sin næring. Etter unionsoppløsningen i 1905 har den grenseoverskridende reindriften vært gjenstand for forhandlinger, reguleringer og konflikter, noe som toppet seg i 2005 da arbeidet med en ny beitekonvensjon ble brutt, og senest da to beitetvister fant veien til domstolene. I denne artikkelen gjennomgås utviklingen fra slutten av 1800-tallet og fram til i dag, hvoretter det gjøres betraktninger om rettstvistene og grunnlaget for dem.

Nøkkelord: grenseoverskridende reindrift, Lappekodisillen, reinbeitekonvensjoner, reinbeiterett, samerett

ØYVIND RAVNA (f. 1961) er professor i rettsvitenskap ved Det juridiske fakultet, UiT Norges arktiske universitet. Hans sentrale arbeidsfelt er tingsrett og same- og urfolksrett. Han har bl.a. skrevet bøkene Rettsutgreiing og bruksordning $i$ reindriftsområder (2008), Finnmarksloven - og retten til jorden i Finnmark (2013) og Same- og reindriftsrett (2019).

\section{Innledning 1}

Allerede på 1740-tallet, under arbeidet forut for grensefastsettinga mellom Norge og Sverige, erfarte major Peter Schnitler at den samiske reindriften var basert på reinens naturlige vandringer mellom vinterens snøfattige lavbeiter i innlandet og sommerens friske grøntbeiter ved kysten. Under «Historiske Tildragelser med Sverrigs Lapmark» skriver han at det er en bekjent sak at «Field-Lapperne» er helt avhengige av å oppholde seg «Vesten for Field-Kiølen i Norsk Lapmark» om sommeren, og om vinteren øst før Kjølen i Sveriges Lappmark: [475]

«Thi ligesom de med deres Reen ei kan begaae sig om Vintren i Norge, formedelst at Reen-Moesen er kun liden, Skov her ikke nok haves, og Sneen efter Regnen haardsammen-fryser, at Reen ei kan

\footnotetext{
${ }^{1}$ Artikkelen er basert på en forelesning på kurs i samiske rettsspørsmål, Juristenes Utdanningssenter, Alta, 12. mars 2020.
} 
opsparke, eller med Foeden opgrave den, at de faae deres Føde; Saa kan Reen om Sommeren ei heller leve i Sverrig, for den heftige Heede og Mængde af U-tøyg, hvoraf den skulde styrte; [...].»²

Major Schnitlers forståelse og nøye innsamlede kunnskap om samenes tradisjoner og levemåte bidro til at grensetraktaten mellom Norge og Sverige i 1751 ble utformet med et tillegg omtalt som Lappekodisillen. ${ }^{3}$ Dette tillegget ivaretok samenes nødvendige behov for sine flyttinger over den nylig fastlagte riksgrensen. Lappekodisillen stadfestet således samenes eldgamle rett til å flytte og å beite med rein. Ved å legge vekt på gammel sedvane sikret kodisillen samenes rett til fortsatt flytting over den nye riksgrensen gjennom hjertet av Sápmi. ${ }^{4}$

Den grenseoverskridende reindriften har, etter som tiden har gått, vist seg å ha fătt størst betydning for de sameslektene som etterhvert fikk svensk statstilhørighet og vintertilhold i Karesuando-området i Sverige. ${ }^{5}$ Det skyldes at grensen mellom Norge og Sverige ble fastlagt slik at vinterbeitene ble liggende på svensk side av grensen, mens sommerbeitene ble liggende på norsk side i det som fram til 2020 var Troms fylke. Dette i motsetning til i de sentrale reindriftsområdene i Karasjok- og Kautokeinoområdene, hvor det i 1751 ble tatt hensyn til den samiske reindriften slik at grensen ble trukket inn i daværende svensk område for å redusere samenes behov for å krysse den nye statsgrensen.

Fram til 1883 har den samiske flytting over landegrensen alene vært regulert av Lappekodisillen. Etter det har en rekke bilaterale (og tidsavgrensede) lover og konvensjoner erstattet de forhold kodisillen har regulert. Da den siste reinbeitekonvensjonen, inngått i 1972 med 30 års varighet, utløp i 2002, hadde det ikke lyktes Sverige og Norge å framforhandle en ny beitekonvensjon. Ytterligere tre års forhandlinger førte heller ikke frem. Landene sto da uten noen moderne avtale som regulerte den grenseoverskridende reindriften. Dette ledet til en ensidig lovregulering fra norsk side, mens man fra svensk side påberopte seg Lappekodisillen som hjemmel for den grenseoverskridende reindriften. [476]

I denne artikkelen drøftes de rettslige forpliktelsene knyttet til den grenseoverskridende reindriften, med et særlig fokus på retten samene fra Sverige har til reinbeite i Norge. ${ }^{6}$ Som en del av rettsgrunnlaget for dagens grenseoverskridende reindrift har det vært naturlig også å vie Lappekodisillens rettslige betydning betydelig oppmerksomhet.

${ }^{2}$ Peter Schnitler, Major Peter Schnitlers grenseeksaminasjonsprotokoller 1742-1745, bind III, ved Lars Ivar Hansen og Tom Schmidt, 1985, s. 24 (s. 42-43 i originalprotokollen).

${ }^{3}$ Første Codicill og Tillæg til Grendse-Tractaten imellem Kongerigerne Norge og Sverrig Lapperne betreffende, 2. oktober 1751. Kodisillen ble inntatt i Norges lover i 1991 og ligger i dag på lovdata: https://lovdata.no/dokument/NL/lov/1751-10-02 (22. mars 2020).

${ }^{4}$ Sápmi eller Sámiid eatnan er samenes egenbetegnelse på deres tradisjonelle landområder.

${ }^{5}$ Den grenseoverskridende reindriften har fram til 1972 også hatt stor betydning lenger sør i Sápmi, hvoretter den ble strengt nedregulert, se punkt 6 nedenfor.

${ }^{6}$ Den grenseoverskridende reindriften er viet betydelig plass i forskning og utredninger. Uten å være fullstendig kan det vises til Ove Bjarnar, Forhandlinger om ny reinbeitekonvensjon mellom Norge og Sverige 1959-1972, hovedoppgave, Tromsø 1982; NOU 1984: 18 Om samenes rettsstilling; Lars-Nila Lasko, «Lappcodicillen av 1751 - var det samernas Magna Charta?», Dieđut 1/1989, Kautokeino; Kirsti Strøm Bull, «Reindriftens rettshistorie 1852-1960», i NOU 2001: 34 Samiske sedvaner og rettsoppfatninger, s. 85-248; Steinar Pedersen, «Lappekodisillen i nord 1751-1859. Fra grenseavtale og sikring av samenes rettigheter til grensesperring og samisk ulykke», Dieđut 3/2008, Kautokeino; NOU 2007: 13 Den nye sameretten, s. 401-409; Nils Johan Päiviö, «Gränsöverskridande renskötsel. Historisk belysning», i NOU 2007: 14 Samisk naturbruk og retts-situasjon fra Hedmark til Troms, s. 499-544; Geir Hågvar, «Svenske samers rett til reindrift i Troms», Lov og Rett, 2008 s. 27-32; Øyvind Ravna, «Lappekodisillen av 1751 og dens rettslige betydning i dag», Lov og Rett, 2010 s. 392-406; og Uno Nesvik og Øyvind Ravna, «Adgangen til å regulere svensk reinbeiting i Norge med norsk reindriftslov», Retfcerd, 2018 s. 51-69. 


\section{Lappekodisillens tilblivelse og normative betydning}

Da Sverige tapte den store nordiske krigen i 1721, og styrkeforholdet i Skandinavia ble mer jevnbyrdig, oppsto det en mulighet for å fastlegge riksgrensen mellom Norge og Sverige. ${ }^{7}$ Etter noen famlende fors $\varnothing \mathrm{k}$ på 1720- og -30-tallet startet Danmark-Norge og Sverige i 1738 forhandlingene og undersøkelsene som skulle lede fram til en grensetraktat i 1751.

I 1742 ble major og jurist Peter Schnitler oppnevnt fra dansk-norsk side til å delta i dette arbeidet. Hans grundige rettslige, topografiske og etnografiske undersøkelser, mye av dette av stor nytte for ettertiden bl.a. når det gjelder forståelsen av samenes bruk av land og vann, ${ }^{8}$ bidro til at det ble gitt et tillegg til grensetraktaten - senere omtalt som lappekodisillen. [476]

Lappekodisillen stadfestet samenes rett til å krysse den nye riksgrensen og til å nytte beitene uavhengig av statsgrensen grunnet $\mathrm{i}$ «gammel Sædvane», for dermed å sikre samenes tradisjonelle leveveger og kultur. Dette ble nedfelt i $§ 10$ :

«Saasom Lapperne behøve begge Rigers Land, skal det efter gammel Sædvane være dennem tilladt, Høst og Vaar, at flytte med deres Rehn-Hiorder over Grendsen ind i det andet Rige. Og herefter som tilforn, lige med Landets Undersaatter [...], at betiene sig af Land og Strand til Underholdning for deres Dyr og sig selv, da de venligen skal imodtages, beskyttes og hielpes til Rette, endogsaa udi Krigs-Tider [...]; Og [...] altid blive som egne Undersaatter anseede og haandhævede paa hvilken Side de sig da som fremmede opholde.»

Lappekodisillen ble dermed den første bilaterale avtalen som beskyttet samisk kultur og næring. Foruten å kodifisere retten til å krysse landegrensen etter gammel sedvane fastslo kodisillen et likebehandlingsprinsipp for samer, uavhengig av statlig tilhørighet, jf. formuleringen «lige med Landets Undersaatter [...], at betiene sig af Land og Strand».

Så vel kodisillens rettslige status som likebehandlingsprinsipp synliggjøres ved at kodisillen på 1800tallet også ble brukt som nasjonal lov. En høyesterettsdom av 21. juni 1862, hvor to reindriftssamer var tiltalt for urettmessig å ha tatt never og trevirke på privat eiendom, gir et normativt bilde av dens datidige betydning. ${ }^{9}$ Saken kom opp fordi en godseier i Vefsn, proprietær Christian Holst, krevde betaling for bruk av strekninger samene nyttet til sine flyttinger, samt for bruk av trevirke under oppholdet. Anmeldelsen og kravet til proprietæren førte ikke fram; førstvoterende dommer kom til at samene måtte frifinnes da de i alt vesentlighet var fullt ut berettiget til den bruk de var tiltalt for:

«Allerede det historiske Forhold mellem Lapperne som de oprindelige Beboere af Landet og de indvandrede norske Eiendomsbesiddere tilsiger, at man maa opretholde og beskytte den Brugsret, som hine [samene] selv efter Okkupationen fra Sidstnævnte Side ere vedblevne.»

${ }^{7}$ Oscar Albert Johnsen, Finmarkens politiske historie. Aktmoessig fremstillet, Kristiania 1923, s. 154. Inntil da var kun grensen mellom Bohuslän og Smålenene (den sørøstlig del av dagens Viken fylke) fastsatt i en traktat fra 1661.

${ }^{8}$ Eksaminasjonsprotokoller, journaler, kart og kopibøker fra Schnitlers arbeid for grensekommisjonen finnes bevart i Grensearkivet i RA, Oslo. Protokollene er utgitt som Major Peter Schnitlers grenseeksaminasjonsprotokoller 1742-1745, 3 bind, 1929-85 (bind 2 ved J. Qvigstad og K. B. Wiklund, 1929; bind. 1 ved K. Nissen og I. Kvamen, 1962; og bind 3 ved L. I. Hansen og T. Schmidt, 1985).

${ }^{9}$ Delvis inntatt i Rt. 1862 s. 654. Publiseringen i Norsk retstidende var den gang ikke fullstendig, se Torstein Eckhoff og Jan Helgesen, Rettskildelaere, 5. utg., Oslo 2001, s. 156-157, og kunne derfor ikke stå som selvstendig henvisning. Dommen er i helhet gjengitt i NOU 1984: 18 s. 654-657, avskrift av skriftlig voteringsprotokoll, Høyesteretts arkiv. 
Høyesterett viste videre til at samene kunne ha påberopt seg lovens «Grunnsætning om Hævd paa Brug». Det var imidlertid ikke nødvendig å nytte denne hjemmel da man kunne gå til en mer positivrettslig bestemmelse, nemlig lappekodisillen $\S 10$, som hadde forutsatt at «den for Lapperne aldeles nødvendige Omvanking med Reenhjorder ogsaa i Fremtiden vilde finde Sted». [477]

Ennå i 1875 hadde lappekodisillen en sterk plass i norske juristers bevissthet. Professor i rettsvitenskap og statsøkonomi Torkel H. Aschehoug skrev i sin statsforfatningsmonografi at Norge ikke hadde rett til «at bryde den Sædvane, ifølge hvilken de svenske Lapper i umindelige Tider hver Vaar søgt ned til den norske Kyst». ${ }^{10}$

Ved å anerkjenne samiske sedvaner og næringer, herunder tradisjonell bruk av land og vann på tvers av riksgrensen, har Lappekodisillen stått i en særstilling som folkerettslig traktat i samisk sammenheng helt fram til vår tid. Den har da også blitt omtalt som samenes Magna Charta og som et vitnemål om høy rettskultur hos traktatlandene. ${ }^{11}$ Av interesse er også kodisillens regler om en samisk rettergangsordning. ${ }^{12}$

\section{Jordbruket ekspanderer, og lappekodisillen settes ut av kraft}

Etter hvert som bureisere i økende grad ryddet skog og fjellvidder og etablerte seg nær opptil reindriftsområdene, oppsto interessekonflikter mellom jordbruk og reindrift. Sverige og Norge siktet mot å løse disse konfliktene gjennom en svensk-norsk felleslovgivning vedtatt i 1883, omtalt som felleslappeloven.$^{13}$ Loven, som avløste (men ikke opphevet) lappekodisillen, prioriterte jordbrukernes interesser framfor reineiernes, og er mest kjent for å ha innført objektivt, solidarisk erstatningsansvar for skade reinen kunne forårsake på bøndenes engsletter og utslåtter, samt reinbeitedistrikter for å ansvarliggjøre reineierne. ${ }^{14}$ Loven ble ikke gjort gjeldende i Finnmark. [478]

I Troms, derimot, regulerte loven også beitetidene for samene fra Sverige, som ble begrenset til tidsrommet fra mai til september. Dette hadde imidlertid ikke vesentlig betydning da disse områdene i all hovedsak var sommerbeiter. Loven bidro like fullt til at jordbruket, som ble sett på som langt viktigere for landet, både kulturelt, økonomisk og bosetningsmessig, fikk «forkjørsrett», mens reindriften ble pålagt en «vikeplikt».

Lappekommisjonen av 1897, som hadde som mandat å utarbeide en ny reindriftslov, uttrykte dette noen år senere slik:

${ }^{10}$ Torkel H. Aschehoug, Norges nuvarende statsforfatning, Bind I, Christiania 1875, s. 70 og 75.

${ }^{11}$ Se «Lappcodicillen av 1751 - var det samernas Magna Charta?», Dieđut 1/1989, Kautokeino, og Lars Ivar Hansen og Bjørnar Olsen, Samenes historie fram til 1750, Oslo 2004, s. 277.

${ }^{12}$ Ifølge $\S 15$ skulle det beskikkes en «Lappe-Lænsmand og 2 Laug Rettes Mænd» i hvert distrikt hvor det foregikk flytting på tvers av grensen. Foruten å holde orden på flyttingen og kreve inn pålagte avgifter skulle de også administrere en egen «Lappe-Ret», jf. §§ 22-27, som hadde myndighet til å avgjøre bestemte rettstvister i første instans, herunder saker om «Lappenes Sædvaner». For øvrig inneholdt kodisillen regler om statsborgerskap ( $\S 3-9)$, rett til naturgoder ( $\S 2,10$ og $12-$ 14), nøytralitet i krig ( $\S \S 10$ og 11) og intern forvaltning av bl.a. reindriften og bruken av beiteområdene (§§ 15-21).

${ }^{13}$ Lov 2. juni 1883 angaaende Lapperne i de forenede Kongeriger Norge og Sverige.

${ }^{14}$ Øyvind Ravna, Same- og reindriftsrett, Oslo 2019, s. 88. På denne tiden kom en ny rettssak hvor lappekodisillen ble påberopt. Endret syn på samisk kultur og tilstedeværelse bidro imidlertid til at kodisillen ikke lenger var i stand til å ivareta samenes rettigheter. I denne dommen fra Rørosområdet, inntatt i Rt. 1892 s. 411, het det at «der [er] liden Opfordring til at løse denne Kollission paa en saadan Maade, at de ældste existerende Rettigheder i væsentlig Grad vilde ødelægges til Fordel for de senere opkommende Rettigheder» (s. 413). Med «ældste existerende Rettigheder» siktet Høyesterett til jordbruket. 
«Saalenge Flytlappernes Næring nyder Lovgivningens Beskyttelse, har den følgelig Krav paa at bydes saadanne Vilkaar, at den kan bestaa. Men i og med dens Stilling som en historisk Overlevering, der i ikke ringe Grad virker som Hemsko paa Udviklingen af bedre berettigede og formaalstjenligere Samfundsinteresser, er Grænserne for dens Krav givne. Og disse Grænser maa efter Forholdets Natur blive vikende. ${ }^{15}$

Lovverket ble tilpasset denne holdningen, hvor det sentrale var å ivareta jordbrukets behov, og hvor reindriften ble sett på som en historisk etterlevning som på sikt skulle avvikles. ${ }^{16}$ Dette skulle bli den bærende tanken bak reindriftsloven av 1933, og synet kom også til å prege de kommende reinbeitekonvensjonene mellom Norge og Sverige.

\section{Unionsoppløsningen og beitekonvensjonen av 1919}

Situasjonen skulle bli mer krevende for samene som var avhengige av å krysse den norsk-svenske riksgrensen. I 1905, i forbindelse med unionsoppløsningen, søkte man fra norsk side å avvikle den «svenske» reinbeiteretten i Norge. ${ }^{17}$ Den gjorde seg særlig gjeldende i Troms, hvor samer fra Karesuando-området var avhengig av de rike sommerbeitene på øyene i Troms. Beiteretten ble sett på som en uønsket servitutt som kunne avløses, hvor det ble argumentert for at Norge ensidig kunne oppsi lappekodisillen.

Under Karlstadforhandlingene høsten 1905 ble de to landene enige om en ny avtale om den grensekryssende reindriften ${ }^{18}$ I denne ble det avtalt at felleslappeloven fra 1883 skulle forbli i kraft i ytterligere 10 år. Videre måtte Norge forplikte seg til å respektere samenes rett til reinbeiting etter Lappekodisillen.

Unionsoppløsning bidro likevel til å vanskeliggjøre den grenseoverskridende reindriften. Fjellsamen Johan Turi fra svensk lappmark skrev i 1910 at «i fordums tid kunne Lapperne græsse renerne i fred overalt». Slik var det ikke lenger:

«Nu er loven imod Lapperne saadan i Norge, at den er som et slør, hvorigennem ikke de skarpeste øjne kan se, hva der er bag det slør. Og dette slør har allerede gjort mange forhold usikre for Lapperne. $\mathrm{Nu}$ er der ikke mer herlig for Lappen i Norge, da han er bleven som en fremmed hund, og fra den gang endnu verre, da Norge blev skilt fra Sverig..11

${ }^{15}$ Indstilling fra den ved Storthingets Beslutning af 27de Juli 1897 og kongelig Resolusjon af 9de September s. A. nedsatte Kommission, der har havt at tage under Overveielse, hvilke Lovregler m. v. vedkommende Lappevæsenet der bliver at istandbringe, efterat Lov om Lapperne i de forenede Kongeriger Norge og Sverige af 2den Juni 1883 er traadt ud af Kraft, Kristiania 1904, s. 196 (uthevet av kommisjonen).

${ }^{16}$ Ravna, Same- og reindriftsrett s. 86-91.

${ }^{17}$ Nikolaus Gjelsvik, «Er Norge forpligtet til at taale de svenske Lappers Renbeiting her i Riget?», i Indstilling fra den ved Storthingets Beslutning af 27de Juli 1897 [...] nedsatte Kommisson, (se note 15) s. 97-127, på s. 126. Se også felleslappeloven $\S 30$, hvor det $i$ annet ledd, siste setning het: «Herved er dog Intet afgjort med hensyn til Spørsmaalet om, hvorvidt nogen af Rigerne har Ret til at fratræde denne Kodicil» (i lovsamlinger trykt etter 1905 er setningen, med henvisning til Karlstadkonvensjonen art. 1, satt i hakeparentes, se f.eks. Almindelig Norsk Lovsamling, Tredie Bind, 1877-1887, Kristiania 1906, s. 541).

${ }^{18}$ Karlstadkonvensjonen 26te Oktober 1905 om Flyttlappers adgang til reinbeiting m.v.

${ }^{19}$ Johan Turi, Muittalus samid birra, en bog om lappernes liv, København 1910, s. 159. 
Etter forhandlinger på overtid ble Sverige og Norge enige om en ny reinbeitekonvensjon 5. februar $1919 .{ }^{20}$ Selv om det ikke lyktes Norge å si opp kodisillen eller avvikle den grenseoverskridende reindriften, innebar konvensjonen en vesentlig innskrenkning i beiteretten til samene fra Sverige. Da den trådte i kraft 1. januar 1923, ble øyene i Troms stengt for Karesuando-samene. Som kompensasjon fikk de tildelt 37 sommerbeitedistrikter på fastlandet med eksklusiv beiterett i perioden 1. mai til 30. september. Norske samer kunne i henhold til konvensjonen samtidig nytte vinterbeiteområder i Sverige uten kvantitetsbegrensninger og klare geografiske avgrensninger. ${ }^{21}$ Konvensjonen ble reforhandlet og resignert uten nevneverdige endringer 14. desember 1949.

Den annen verdenskrig reduserte den grenseoverskridende reindriften i vesentlig grad, og betydelige beiteområder ble liggende ubenyttet. I gjenreisningstiden etter krigen ble det trangere om beitene i deler av Finnmark, og familier derfra fikk tilbud om å flytte til Troms, der myndighetene mente det var bedre plass. Ifølge historieprofessor Bård A. Berg fikk en Kautokeino-familie da tildelt beiter på fastlandsområdet nær Tromsø. ${ }^{22}$ Det ble nå flere om beitene i områdene som historisk sett hadde vært nyttet av samene som krysset riksgrensen med sine reinflokker.

I 1959 ble det innledet forhandlinger om en reinbeitekonvensjon som skulle erstatte 1919konvensjonen. Etter ett års forhandlinger forelå det et kompromiss. Dette ble ikke godtatt fra norsk side, som i stedet gikk til det skritt å si opp 1919-konvensjonen. ${ }^{23}$ Stridstemaet var 1919-konvensjonens § 202 som suspenderte lappekodisillen og Karlstadkonvensjonen, men uten å oppheve disse. Det ble fra svensk side tatt som et uttrykk for at det eksisterte en rett for svenske samer til beite i Norge, mens det fra norsk side ble anført at det kun forelå en traktat mellom de to landene, og ingen samisk beiterett. ${ }^{24}$

Ved forhandlingene innebar det at Norge ikke mente seg bundet av samiske reindriftsrettigheter. Videre utrykte det norske Utenriksdepartementet at den norske regjering også hadde andre hensyn å ta i denne sak:

«For det første må man ta hensyn til den fastboende jorddyrkende befolkning i de landsdeler som berøres av svensk reindrift i Norge [...]. For det annet har landets egne samer et sterkt behov for å kunne utnytte de beiteområder som er reservert for rein. $\rangle^{25}$

Nye forsøk på forhandlinger i 1962 og 1963 lyktes ikke. I 1964 ble det opprettet en ny kommisjon for å forestå forhandlingene. Den kommer jeg tilbake til.

${ }^{20}$ Norge ratifiserte konvensjonen ved lov 18. juni $1919 \mathrm{nr} .7$ om flyttlappenes adgang til reinbeiting $\mathrm{i}$ henhold til konvensjon mellom Norge og Sverige av 5. februar 1919, med ikrafttreden 1. januar 1923.

${ }^{21}$ Ot.prp. nr. 75 (2004-2005) Om lov om endringer i lov 9. juni $1972 \mathrm{nr} .31$ om reinbeiting i henhold til konvensjon av 9. februar 1972 mellom Norge og Sverige om reinbeite.

${ }^{22}$ Thor Anders Angelsen, «Folket som forsvant: Tromsø-samene som ble 'svensksamer'», iTromsø, 28. desember 2018. Berg viser her til at den norske stat i brevs form ga grønt lys til at en Kautokeinofamilie kunne bruke Tromsø-området til sommerbeite. I brevet skrev lappeoppsynsmann Magnus Høeg angivelig at familien kan beholde området rundt Tromsø til sommerbeite, og heller ta striden med de svenske samene når den tid kommer, se https://www.itromso.no/nyheter/2018/12/28/Troms\%C3\%B8-samene-som-ble\%C2\%ABsvensksamer\%C2\%BB-18139877.ece (sist brukt 19. mars 2020).

${ }^{23}$ Bjarnar, Forhandlinger om ny reinbeitekonvensjon mellom Norge og Sverige 1959-1972 s. 11

${ }^{24}$ Bjarnar, Forhandlinger om ny reinbeitekonvensjon mellom Norge og Sverige 1959-1972 s. 12.

${ }^{25}$ Bjarnar, Forhandlinger om ny reinbeitekonvensjon mellom Norge og Sverige 1959-1972 s. 14, med henvisning til UDs arkiv Jnr. 013856 Bd. 6. Rapport fra forhandlingsmøte i Stockholm (mai 1959). 


\section{Altevann-dommen og Utenriksdepartementets standpunkt}

I 1957, to år før konvensjonsforhandlingene i Stockholm startet, fikk Norges vassdrags- og elektrisitetsvesen (NVE) konsesjon for å regulere Altevann, på samisk Álddesjávri. Innsjøen i Indre Troms ligger i kjernen av beiteområdet til Karesuando-samene, og reguleringen ville føre til at omlag 25000 dekar beite ble lagt under vann samtidig [481] som et betydelig areal ble mer eller mindre unyttbart. Det ville igjen påføre samebyene Talma og Saarivuoma betydelige tap av både beiter og fiskemuligheter. ${ }^{26}$

Sommeren 1958 krevde de svenske samenes ombudsmann i Norge tiltak og erstatning i henhold til reguleringsbestemmelsene for Altevann fastsatt i 1957, noe som ledet til en overenskomst mellom ombudsmannen, NVE og svenske og norske myndigheter. Når det gjaldt erstatning for neddemmet beite, ble det med grunnlag i en sakkyndig utredning oppnådd enighet om et beløp på kr 200000 med tillegg av $25 \%{ }^{27}$ For fisket i vassdraget var det $\mathrm{i}$ overenskomsten enighet om at erstatningen skulle fastsettes ved skjønn. Den 21. april 1960 fastsatte skjønnsretten dette beløpet til kr 100000 med tillegg av $25 \%$.

Etter at resultatet forelå, ble det klart at det norske Utenriksdepartementet ikke kunne akseptere det framforhandlede resultatet. Standpunktet til Utenriksdepartementet, som det norske Landbruksdepartementet ikke delte, er i vår sammenheng vel verd å merke seg. Utenriksdepartementet mente at enkelt-samer eller grupper av samer ikke hadde rettigheter i det annet land i medhold av 1919konvensjonen eller på annet grunnlag, og frambar således det samme standpunkt som nylig hadde ført til brudd i konvensjonsforhandlingene. Her lød det slik:

«De eneste rettighetshavere etter konvensjonen var den svenske og norske stat, og spørsmålene om tiltak og erstatning var følgelig en sak som lå under de to stater og alene under dem (Rt. 1968 s. 429 på s. 430).»

Saken kunne ifølge Utenriksdepartementet dermed ikke avgjøres ut fra en overenskomst mellom vassdragsvesenet og de svenske samene som hadde brukt Altevannstraktene til sommerbeite.

Kravene om tiltak og beiteerstatning var, som vi har sett, ikke fremmet for underskjønnet da partene hadde løst disse spørsmålene i minnelighet. På grunn av Utenriksdepartementets standpunkt anmodet prosessfullmektigen for Talma og Saarivuoma om fastsettelse av tiltak og erstatningsbeløp. NVE erklærte seg enig i denne fremgangsmåte.

Overskjønnet ble avhjemlet ved Senja herredsrett 29. mai 1965. Overskjønnsretten la til grunn at tvisten gjaldt om bruksutøvelsen som «de svenske lappbyer» og samer fra disse byer hadde drevet $\mathrm{i}$ Altevannstraktene, var «av en slik art eller er hjemlet i slike rettigheter [483] at den er beskyttet mot det inngrep reguleringen medfører, med den følge at de har krav på tiltak og erstatning». Overskjønnsretten kom til at bruksutøvelsen hadde vært et vesentlig ledd i de svenske flyttsamers næring, «og at den hadde hatt og har en slik fasthet og karakter at bruken måtte anses beskyttet overfor ekspropriantens inngrep i den bestående tilstand» (s. 431). Som erstatning for inngrep fastsatte overskjønnsretten til sammen kr 300 000 med tillegg av $25 \%$ og $4 \%$ rente fra 1 . januar 1960. Overskjønnet godtok dessuten påståtte tiltakskrav, hvor samebyene ble tilkjent kr 33000 med $25 \%$ tillegg for framtidig vedlikehold.

Overskjønnet ble påanket av den norske stat ved Landbruksdepartementet og NVE. Anken førte ikke fram. I det som senere ble omtalt som Altevann-dommen, inntatt i Rt. 1968 s. 429, stadfestet Høyesterett enstemmig overskjønnet, hvor samebyene Talma og Saarivuoma fikk bekreftet sin beiterett grunnet i historisk bruk. Førstvoterende uttrykte det slik:

«Når det gjelder saksforholdet, legger jeg som overskjønnsretten til grunn at slekt etter slekt fra det distrikt hvor byene ligger, i hvert fall ett hundreår før grensen ble fastlagt i 1751, har hatt boplasser

\footnotetext{
${ }^{26}$ Fremstillingen av skjønnsavgjørelsene og bakgrunnen for dommen er basert på Rt. 1968 s. 429, på s. 429 til 432.

${ }^{27}$ Et tillegg på $25 \%$ ved inngrep relatert til vassdragsreguleringer er hjemlet i lov 14. desember $1917 \mathrm{nr}$. 17 om regulering og kraftutbygging i vassdrag $\S 30$ tredje ledd.
} 
ved Altevann med stabbur, skillegjerder, båter og annen redskap de trengte, og at lappene senere årvisst har brukt området med beite og fiske. Man må da som overskjønnsretten kunne fastslå at fra historisk tid har lappene i dette bestemte område etablert og festnet en nødvendig bruk i næring» (s. 437-438).

Med bakgrunn i denne erkjennelsen fant Høyesterett «at den foreliggende neddemning er et inngrep i en så fast og konsentrert bruk av beite og fiske ved Altevann at eksproprianten må betale erstatning» (s. 438).

Dommen er i ettertid blitt et prejudikat for reindriftssamenes ekspropriasjonsrettslige vern - og langt på vei også for at reindriftens rettsgrunnlag er alders tids bruk.

\section{1972-konvensjonen - sto de to statene fritt til å regulere}

\section{samenes rett?}

Etter at forhandlingsforsøkene fra 1959 til 1963 ikke hadde ført fram, ble det i februar 1964 oppnevnt en ny forhandlingskommisjon med fire medlemmer fra hvert land omtalt som Den norsk-svenske reinbeitekommisjonen, ledet av den danske ambassadøren Niels Svenningsen. Denne kommisjonen konkluderte enstemmig med at de svenske samebyene sør for Torneträsk ikke hadde behov for sommerbeiter i Nordland, og at samebyene nord for Torneträsk hadde begrenset behov for vår- og sommerbeite i Troms, da det var skjedd en omlegging av bruken i de norske sommerbeiteområdene på 1950- [484] og -60-tallet. ${ }^{28}$ Kommisjonen erkjente dog at reguleringene ville medføre ytterligere omlegginger.

Innstillingen ble et slag mot samene fra Sverige sine beiterettigheter i Norge. ${ }^{29}$ Etter de etterfølgende forhandlinger ble det undertegnet en ny reinbeitekonvensjon 9. februar 1972, gjort til norsk rett i en egen lov. ${ }^{30}$ Konvensjonen ledet til en markant reduksjon i sommerbeiteområder til Talma og Saarivuoma i Norge, med hele $71 \%$, fra 13760 til $3940 \mathrm{~km}^{2} .{ }^{31}$ For områdene i Nordland var reduksjonen $67 \%$.

Konvensjonsforhandlingene var basert på at nasjonalstatene sto fritt til å regulere samenes rettigheter et standpunkt Norges Høyesterett hadde satt til side i Altevann-dommen fire år tidligere, og som således allerede den gang neppe var gjeldende rett. At Høyesterett fire år tidligere også hadde stadfestet at de samme samebyene hadde beiterett i Norge grunnet i historisk bruk, ble heller ikke vektlagt. Det er således et rettslig paradoks at de samene som vant fram i Altevann-dommen, en dom som er blitt et prejudikat for reindriftssamenes selvstendige rettsgrunnlag og ekspropriasjonsrettslige vern, senere er de som er blitt fratatt de største beiteområdene i Norge uten noen form for kompensasjon.

En kan imidlertid merke seg at Sverige og Norge i en noteveksling av 28. april 1972 erklærte at adgangen til beite på den andre siden av riksgrensen skal opprettholdes så lenge det finnes samer i de to landene som er avhengig av en slik beiteform for å bevare sin livsform og næring. ${ }^{32}$

${ }^{28}$ Ot.prp. nr. 75 (2004-2005) Om lov om endringer i lov 9. juni $1972 \mathrm{nr} .31$ om reinbeiting i henhold til konvensjon av 9. februar 1972 mellom Norge og Sverige om reinbeite s. 2. Innstilling avgitt av den Norsk-svenske reinbeitekommisjon av 1964 (Oslo, UD 1967).

${ }^{29}$ Bjarnar, Forhandlinger om ny reinbeitekonvensjon mellom Norge og Sverige 1959-1972 s. 63.

${ }^{30}$ Lov 9. juni $1972 \mathrm{nr}$. 31 om reinbeiting i henhold til konvensjon av 9 februar 1972 mellom Norge og Sverige om reinbeite.

${ }^{31}$ NOU 2007: 13 s. 403, med henvisning til Innstilling fra Norsk-Svensk Reinbeitekommisjon av 1997, 2001 s. 45.

${ }^{32}$ St.prp. nr. 106 (1971-72) Om samtykke til ratifikasjon av en konvensjon av 9. februar 1972, med tilhørende protokoll og noteveksling mellom Norge og Sverige om reinbeite, s. 8, og noteveksling av 28. april 1972. 
Etter initiativ fra reineiere i Troms og nordlige Norrbotten ble konvensjonen av 1972 revidert i 1984 uten at det innebar endringer av prinsipiell karakter. ${ }^{33}[\mathbf{4 8 5}]$

\section{Forhandlingene om en ny konvensjon}

Reinbeitekonvensjonen av 1972 fastsatte i § 76 at konvensjonen skulle gjelde i 30 år, dvs. fram til 30. april 2002. I henhold til konvensjonens $\S 69$ ble i 1997 Den blandede norsk-svenske reinbeitekommisjon nedsatt. Den skulle utrede spørsmålet om fortsatt behov for grensekryssende reindrift og hvordan den eventuelt skulle foregå. Kommisjonen avgav en enstemmig innstilling i mai 2001 med utkast til ny konvensjon.

Enstemmigheten til tross, utkastet ledet ikke til enighet mellom de to landene og deres samer. Høringsuttalelsene viste at det var svært forskjellige oppfatninger om utkastet hos reindriftssamene i Norge og Sverige. Av proposisjonen til den norske endringsloven av 2005 framgår det at reindriftsnæringen på norsk side var negativ til utkastet da det angivelig ikke ville sikre den tradisjonelle reindriften basert på fornuftig beitebruk, og at den norske reindriften totalt sett ville få dårligere rammevilkår enn etter gjeldende konvensjon. ${ }^{34}$ Norske Reindriftssamers Landsforbund anbefalte på dette grunnlag at det ble utarbeidet et nytt utkast forut for sluttforhandlinger med Sverige. Heller ikke det norske Sametinget støttet forslaget.

I Sverige var bildet et annet; i den norske proposisjonen er det vist til at den svenske reindriftsnæringen ikke uttrykte den samme motstand mot forslaget som var tilfellet i Norge, idet den i hovedtrekk så sine interesser tilfredsstillende ivaretatt i det foreliggende utkastet. ${ }^{35}$

Den svenske sjefsforhandleren Lars Norberg anførte senere at 1972-konvensjonen, sett fra svensksamisk side, i juridisk henseende var beheftet med to grunnleggende feil. Det var 1) at den svenske regjering hadde forhandlet fram en avtale om de svenske samenes private rettigheter mot deres vilje, noe den ikke hadde adgang til, og 2) at den svenske regjeringen aksepterte inngrepene uten å kreve erstatning for tapt beiteland. 1972-konvensjonen ble således «en kvärnsten om halsen» på de svenske samene. ${ }^{36}$

Det ble etterhvert klart at det gjensto et betydelig arbeid før en ny konvensjon kunne signeres, noe som gjorde at 1972-konvensjonen ble forlenget med tre år fram til 30. april 2005. Allerede tidlig i de påfølgende forhandlingene meddelte norsk side at kommisjonsforslaget måtte forkastes. ${ }^{37}$ Særlig $\mathrm{i}$ to spørsmål var det stor avstand mellom partene. Det ene gjaldt fordelingen av beiteområdene mellom norske og svenske reindriftssamer, og det andre gjaldt et svensk ønske om å innta en konstatering av privatrettslige beiterettigheter i konvensjonen. ${ }^{38}$ Av proposisjonen framgår det videre at bak begge disse spørsmål lå det en oppfatning fra svensk side om at de svenske samebyene fra gammelt av har hatt en rett til reinbeite i Norge - en rett som urettmessig var blitt fratatt dem ved de forskjellige

reinbeitekonvensjonene, senest i 1972. Det ble anført at svenske samer, tross konvensjonsreguleringer og innflytting av norske reindriftssamer, fremdeles innehadde slike rettigheter. ${ }^{39}$

${ }^{33}$ En del av grensene trukket opp i 1972, var umulig å opprettholde. I oktober 1984 ble det gjort visse endringer i konvensjonen for å rette på dette, noe som ble innarbeidet i 1972-loven ved lov 29. mars $1985 \mathrm{nr}$. 17 om endringer i lov av 9. juni 1972 om reinbeiting [...].

${ }^{34}$ Ot.prp. nr. 75 (2004-2005) Om lov om endringer i lov 9. juni 1972 nr. 31 om reinbeiting i henhold til konvensjon av 9. februar 1972 mellom Norge og Sverige om reinbeite s. 2.

${ }^{35}$ Ot.prp. nr. 75 (2004-2005) s. 2-3.

${ }^{36}$ Udtja Lasse [Lars Norberg], Begrav mitt hjärta vid Udtjajaure, Stockholm 2007, s. 72. Diplomaten Norberg var sjefsforhandler for den svenske delegasjonen under reinbeiteforhandlingene 20032005.

${ }^{37}$ Norberg, Begrav mitt hjärta vid Udtjajaure s. 84-85.

${ }^{38}$ Ot.prp. nr. 75 (2004-2005) s. 3 sp. 2.

${ }^{39}$ Ot.prp. nr. 75 (2004-2005) s. 3 sp. 2. 
Fra norsk side var man ikke lenger uenige $i$ at de svenske samebyene hadde rettigheter som måtte respekteres. Men Norge kunne ikke akseptere den foreslåtte svenske konstateringen av rettstilstanden; de norske forhandlerne ville heller overlate til domstolene å ta stilling til hvilke privatrettslige rettigheter som forelå, herunder hvilke konsekvenser tidligere konvensjoner har hatt i den forbindelse. ${ }^{40}$ Dermed stilte man fra norsk side fortsatt spørsmål ved eksistensen av rettighetene for de svenske samebyene. Forhandlingene førte ikke fram innen rammen av tidsforlengelsen.

\section{Brudd og nye forhandlinger}

Fra svensk side ble en ytterligere konvensjonsforlengelse avvist, og 21. januar 2005 avga Sverige en note der det ble henvist til Lappekodisillen av 1751 som grunnlag for den grenseoverskridende reindriften etter 1. mai 2005. Dette innebar at lappekodisillen igjen ble det gjeldende folkerettslige dokumentet for den grenseoverskridende reindriften mellom Norge og Sverige. Den svenske regjeringen la således til grunn at det var mulig å anvende kodisillen i situasjonen som da oppsto, ${ }^{41}$ samtidig som sjefsforhandleren anførte at avvisningen av en videreføring av 1972-konvensjonen styrket de svenske samenes posisjon. ${ }^{42}$

Selv om det norske Landbruks- og matdepartementet erkjente Lappekodisillens betydning, delte den ikke oppfatningen om at den grenseoverskridende reindriften kunne reguleres av denne. Da kodisillen ikke anga bestemte beiteområder, og det hersket stor uenighet mellom samene om hva som var sedvanemessige områder for beite, ville en forvaltning etter kodisillen alene «medføre en situasjon med et regelverk som er ukjent og uforutsigbarhet [...] [hvor] dette lett kunne medføre konflikter og uoversiktlige forhold som verken næringen selv eller myndighetene vil være [487]tjent med». ${ }^{43}$ Det er bakgrunnen for at Norge ensidig valgte å videreføre reinbeiteloven, ${ }^{44}$ som en presisering og oppdatering av det materielle innholdet i Lappekodisillen. Dette innebar imidlertid forskjellig lovgivning i Sverige og Norge når det gjaldt samenes adgang til reinbeiting i nabolandet, noe man ikke hadde hatt tidligere. ${ }^{45}$

Norges ensidige lovvedtak bidro til å akselerere beitekonflikten. Kort tid etter at lovproposisjonen var fremmet, oversendte Sveriges utenriksminister Laila Freivalds et brev til sin norske kollega Jan Petersen, hvor det ble anført at «den föreslagna norska lagstiftningen inte står i överensstemmelse med Norges folkrättsliga åtaganda enligt kodicillen». ${ }^{46} \mathrm{I}$ brevet ble det også anført viktigheten av «våra regjeringar finner en lösning på renbetesfrågan». Det ble videre påpekt at den svenske regjeringen er beredt til å fortsette forhandlingene om dette «på ett sätt som tilgodoser båda svenska og norska samers rättigheter och interesser så att det gränsöverskridande renbetet kan bedrivas under ordnade former i båda länderna».

I sitt svar avviste den norske utenriksministeren naturlig nok at Norge brøt folkeretten, og presiserte at «de norske reguleringsbestemmelsene selvsagt vil være i samsvar med våre folkerettslige forpliktelser i henhold til Lappekodicillen», samtidig som det også her ble gitt uttrykk for at forhandlingene snarest

${ }^{40}$ Ot.prp. nr. 75 (2004-2005) s. 3.

${ }^{41}$ Ot.prp. nr. 75 (2004-2005) s. 4.

${ }^{42}$ Norberg, Begrav mit hjärta vid Udtjajaure s. 107.

${ }^{43}$ Ot.prp. nr. 75 (2004-2005) s. 1 sp. 1.

${ }^{44}$ Se lov 17. juni $2005 \mathrm{nr} .100$ om endringer i lov 9. juni $1972 \mathrm{nr} .31$ om reinbeiting i henhold til konvensjon av 9. februar 1972 mellom Norge og Sverige om reinbeite. Lovgiver valgte å videreføre loven som lov 9. juni 1972 nr. 31, men med endret tittel, «lov om svensk reinbeiting i Norge og norsk reinbeiting i Sverige», se Ot.prp. nr. 75 (2004-2005) s. 6.

${ }^{45}$ Norberg, Begrav mit hjärta vid Udtjajaure, er svært kritisk til loven og skriver at «[d]en var i uppenbar strid mot folkrätten» (s. 105).

${ }^{46}$ Utenriksdepartementets arkiv: Brev fra utriksminister Laila Freivalds til utriksminister Jan Petersen, datert 11. mai 2005. 
burde gjenopptas. ${ }^{47}$ Den norske ministeren viste videre til brevvekslingen av 28. april 1972 (se ovenfor) og påpekte at «svenske samers privatrettslige rettigheter til reinbeite i Norge ikke er grunnet på kodicillen, men på norsk retts regler om alders tids bruk». Man kan merke seg at standpunktet fra norsk side nå var at «[s]like privatrettslige rettigheter vil norske myndigheter selvsagt respektere». Det ble samtidig påpekt at det bare er domstolene som kan avgjøre om det i dag foreligger slike rettigheter grunnet $\mathrm{i}$ alders tids bruk i et konkret beiteområde.

Forhandlingsbruddet innebar at samebyene Saarivuoma og Talma, som nå ikke lenger var bundet av 1972-konvensjonen, nyttet muligheten til å ta i bruk deler av de [488] områdene de var blitt fratatt i 1972. Dette resulterte i en rekke konflikter i Troms i perioden etter 2005.

Nye konvensjonsforhandlinger ble innledet i desember 2005. Etter drøye tre år så det ut til at de to landenes delegasjoner hadde kommet fram til en løsning 24. februar 2009. Løsningen innebar at de svenske samene fikk økt sine beitearealer i Norge, en løsning også daværende landbruks- og matminister Lars Peder Brekk uttrykte glede over å ha kommet i havn med. ${ }^{48}$

Konvensjonen ble deretter sendt på høring. I 2013 fikk en arbeidsgruppe, bestående av sametingene i Norge og Sverige og reindriftens organisasjoner i begge land, tross enigheten i 2009, i oppdrag å arbeide videre for å komme til enighet om en ny norsk-svensk reinbeitekonvensjon. Resultatet av dette arbeidet forelå i mars 2014, og de to lands aktuelle departementer skulle etter dette gi en felles skriftlig tilbakemelding med det utgangspunkt at en ny konvensjon skulle ratifiseres i løpet av 2016. I januar 2016 informerte imidlertid den svenske landsbygdsministeren om at Sverige skulle foreta en nærmere juridisk utredning av forslaget. Utredningen forelå i juni 2016, og samme høst sendte det svenske næringsdepartementet utredningen på høring. I sin høringsuttalelse har det svenske Sametinget gått imot forslaget til ny konvensjon. ${ }^{49}$

I brev av 11. juli 2017 fra landsbygdminister Sven-Erik Bucht blir det kunngjort at Sverige ikke vil ratifisere forslaget til ny konvensjon av februar 2009. Det blir i stedet foreslått å gjenoppta forhandlingene. ${ }^{50}$ Status i skrivende stund er at man ikke er nærmere en ny konvensjon enn det man var $\mathrm{i}$ 2009.

Ifølge avdelingsdirektør Morten Floor i Landbruks- og matdepartementet har situasjonen bl.a. ført til at den norske reindriften er utelukket fra vinterbeiter i Sverige samtidig som svenske reineiere bruker områder i tid og rom utover det som følger av gjeldende lovgivning. Den fører også til utilstrekkelig vedlikehold av tidligere konvensjonsgjerder, som igjen fører til sammenblanding og driftsmessige problemer og generelt til frustrasjon og usikkerhet knyttet til rettighetssituasjonen for norsk reindrift $\mathrm{i}$ området. ${ }^{51}[489]$

\section{Rettstvister - har lovreguleringer forrang fremfor rettigheter grunnet i alders tids bruk?}

Parallelt med forhandlingene om en ny reinbeitekonvensjon har uenighet om beiterettigheter de senere årene ført til flere rettstvister. Den 15. mars 2017 frifant Oslo tingrett Staten v/Landbruks- og matdepartementet og Statskog SF for et krav om vinterbeiterett i Norge (TOSLO-2015-158639) reist av Talma sameby. Som vist ovenfor har beiteretten for samer fra Sverige i Norge vært begrenset til

\footnotetext{
${ }^{47}$ Utenriksdepartementets arkiv: Brev fra utenriksminister Jan Petersen til utenriksminister Laila Freivalds, datert 13. mai 2005.

${ }^{48}$ Regjeringen.no (historisk arkiv): http://www.regjeringen.no/nb/dep/lmd/aktuelt/nyheter/2009/feb09/reindrift-ny-konvensjonmellom-norge-og-.html?id=547378 (sist besøkt 22. mars 2020).

${ }^{49}$ Meld. St. 32 (2016-2017) Reindrift. Lang tradisjon - unike muligheter s. 59-60.

${ }^{50}$ Regjeringen.no: Grenseoverskridende reindrift mellom Norge og Sverige - Kort historikk.

${ }^{51}$ Morten Floor, Nytt fra LMD, powerpoint presentasjon, kurs i samiske rettsspørsmål, Juristenes Utdanningssenter, Alta, 12. mars 2020.
} 
tidsrommet mai til september siden 1883. Tingretten var enig i at Talma sameby gjennom alders tids bruk har rett til nødvendig beite i Norge. Tingretten fant imidlertid ikke at det innebar at Talma har rett til vinterbeite i Norge.

Etter at prosessuelle forhold omkring hvem som kunne saksøkes ble avklart, jf. LB-2017-97958-1 og HR-2018-1463-U, ble saken realitetsbehandlet av Borgarting lagmannsrett. I dom 7. januar 2019 (LB2017-97958-2) stadfestet lagmannsretten dommen fra tingretten. Borgarting lagmannsrett begrunnet sin dom bl.a. med at «reindriftsrettigheter basert på alders tids bruk eller annet ting[s]rettslig grunnlag, ikke kan utvikle seg og bli mer omfattende etter at rettighetene har blitt gjenstand for sammenhengende offentligrettslig regulering over tid», med andre ord kunne ikke beiteretten strekke seg utover fastlagte beitetider. Anken ble ikke tillatt fremmet for Høyesterett (HR-2019-766-U).

Også Saarivuoma sameby har saksøkt staten. I motsetning til Talma krever Saarivuoma rett til sommerbeite utenfor det som siden 1972 har vært konsesjonsbeiteområdet. Videre krever samebyen at tidspunkt for inn- og utflytting kan varieres ut fra driftsmessige behov. 27. november 2018 kom Senja tingrett (TSENJ-2018-26537) til at beitereguleringene i den norske grensebeiteloven har forrang foran en eventuell sedvanerett reineierne i Saarivuoma sameby måtte ha i Norge, og frifant på dette grunnlag den norske stat. Senja tingrett var imidlertid av den oppfatning at den rettskildemessige situasjonen er uklar:

«På den ene siden er lovens ordlyd klar. Denne åpner ikke opp for en bruk ut over det som følger av $\mathrm{de}[\mathrm{n}] \mathrm{s}$ ordlyd og forskrift. Lovens formål, systematikk, og fast forvaltningspraksis underbygger dette. På den andre siden foreligger det tungtveiende hensyn som tilsier at rettigheten må respekteres, og at saksøker skal nytte sin rettighet i samsvar med stiftelsesgrunnlaget. Uttalelser i forarbeidene og ikkeratifisert konvensjon underbygger dette standpunkt. Det vises ytterligere til uttalelser fra Høyesterett som kan tale i denne retning.

Samlet sett er det rettens oppfatning, dog under noe tvil, at det er lovens ordlyd og lovgivers vilje som må tillegges avgjørende vekt.» [490]

Tingretten begrunner således sitt standpunkt med at grensereinbeiteloven med forskrift uttømmende angir i hvilke områder og til hvilke tider grenseoverskridende reinbeite kan finne sted. Tingretten viser videre til at den samlede ressursutnyttelsen i dette området tilsier at man må ha en forutberegnelighet og en stabil situasjon hva gjelder beitebruken, hvor «en situasjon der saksøker gis adgang til å nytte et område som går ut over det som følger av loven sammenholdt med forskrift kan gi grunnlag for en svært uoversiktlig situasjon».

Tross uklarhetene i den rettskildemessige situasjonen ble staten frifunnet. Tingretten uttalte imidlertid:

«Det erkjennes dog at resultatet kan fremstå urimelig for saksøker, og retten har vært i tvil hva gjelder dette standpunkt. Dette begrunnes med at retten ser at saksøkers utnyttelse av rettigheter opparbeidet gjennom alders tid blir begrenset som følge av forhandlinger mellom den norske og svenske stat.»

Selv om Senja tingrett ikke tar stilling til om det foreligger rettigheter grunnet $i$ alders tids bruk på det konkrete tvisteområdet, setter den med dette lovens bestemmelser og reelle hensyn foran reglene om alders tids bruk. Den usikkerhet og urimelighet i resultatet som tingretten uttrykker, er imidlertid en oppfordring for Saarivuoma sameby til å anke saken, noe den har gjort. Tvisten er i skrivende stund ikke rettskraftig avgjort. ${ }^{52}$

${ }^{52}$ Ankeforhandlingene i sak 19-068920ASD-HALO ble gjennomført 4. til 7. november 2019 ved Hålogaland lagmannsrett. Hålogaland lagmannsrett v/ førstelagmannen har imidlertid i brev 14. januar 2020, med henvisning til Høyesterett i HR-2019-2395-A, kommet til at retten var feil sammensatt idet en jordskiftelagdommer utgjorde et av rettens medlemmer, jf. domstolloven $\S 12$ annet ledd. Nye ankeforhandlinger ble gjennomført første uke i juli 2020 og dom avsagt 25. august 2020. Hålogaland lagmannsrett kom til samme resultat som Senja tingrett og har i det vesentlige sluttet 


\section{Drøfting og avslutning}

Samene fra Sverige har gradvis fått sine historiske beiteområder i Norge innskrenket fra 1883 fram til i dag. De mest omfattende innskrenkningene i beiteområdene fant sted gjennom konvensjonene av 1919 og 1972 hvor Norge (og Sverige) baserte sine beslutninger på at nasjonalstatene sto fritt til å regulere samenes rettigheter. Samtidig er det også en realitet at samer fra Kautokeino-området med den norske stats bifall og støtte har fătt [491] ta i bruk områdene de svenske samene tidligere har brukt, og har langtidig tilknytning til. Det har således skjedd en «dobbelt booking» på disse områdene. I den grad de svenske samene har hatt - og har - historiske rettigheter til disse områdene, innebærer det at det foreligger reelle rettslige konflikter knyttet til bruken av disse områdene.

Er det så mulig å si hvem som har beiterett på de omtvistede arealene i Troms i dag basert på de gjennomgåtte rettskilder? Forholder vi oss til lappekodisillen, har samene fra svensk side rett til «efter gammel Sædvane»:

«Høst og Vaar, at flytte med deres Rehn-Hiorder over Grendsen ind i det andet Rige. Og herefter som tilforn, lige med Landets Undersaatter [...], at betiene sig af Land og Strand til Underholdning for deres Dyr og sig selv $[\ldots] »$.

Lappekodisillen er imidlertid skrevet for en annen tid, og den løser ikke spørsmålene dagens moderne reindrift står overfor; om hvem som kan beite hvor. Kan man da, som Norge har gjort, ensidig videreføre en lov og beiteregulering det ikke har lyktes de to landene å reforhandle, og som slik sett regulerer et grenseoverskridende beiteforhold som er eldre enn grensetraktaten og som fram til 2005 har vært forankret i bilaterale overenskomster?

Bruksrettigheter forankret $\mathrm{i}$ alders tids bruk har i praksis samme rettsvern som eiendom, og har ved kollisjon i alminnelighet forrang fremfor rettigheter forankret i lov. ${ }^{53}$ Dette skulle tilsi forsiktighet $\mathrm{i}$ slike reguleringer, $i$ alle fall uten at det først tas stilling til eksistensen og utstrekningen av rettighetene samene fra Sverige måtte ha, og rettighetens grunnlag. Når det gjelder slik eksistens og utstrekning, må det også vurderes om bevisbyrderegelen i reindriftsloven $\S 4$ annet ledd er av relevans.

Ved inngrep i reindriftssamenes reindriftsrettigheter skal det ytes erstatning i samsvar med alminnelige ekspropriasjonsrettslige grunnsetninger, jf. reindriftsloven $\S 4$ tredje ledd. Det må også være det rettslige utgangspunkt ved inngrep i beite- og bruksrettigheter forankret i alders tids bruk for samer fra svensk side, noe som ble slått fast allerede i Altevann-dommen i 1968.

Samtidig må det spørres om ekspropriasjonshjemlene dekker det formål vi har foran oss her, jf. oreigningslova $\S 2$ annet ledd om at «inngrepet tvillaust er til meir gagn enn skade». Det er vanskelig å se for seg at dette vilkåret er oppfylt all den stund det er tale om å ekspropriere beiterett fra en reindriftsgruppe til fordel for en annen. Om man i stedet for oreigningslova skulle velge å nytte ekspropriasjonshjemmelen i reindriftsloven $\S 7$ første ledd, vil man like fullt støte på samme krav som i oreigningslova. Videre kan det spørres om inngrep også krenker FNs konvensjon om sivile og politiske rettigheter art. 27 som beskytter minoritetsfolks rett til å utøve sin kultur m.m.

Om samene fra Sverige, her Saarivuoma sameby, ennå har i behold beiterettigheter i medhold av alders tids bruk utenfor dagens konvensjonsområde, får vi ikke svar på før det foreligger en rettskraftig dom i tvisten mellom Saarivuoma og den norske stat. Da vil vi trolig også få svar på om rettigheter forankret i alders tids bruk har forrang fremfor ensidige norske lovreguleringer.

seg til tingrettens begrunnelse. Lagmannsretten finner heller ikke at lovreguleringen som stenger Saarivuoma sameby fra beitene de rådet over inntil 1972, utløser erstatningsansvar.

${ }^{53}$ Kirsti Strøm Bull, Studier i reindriftsrett, Oslo 1997, s. 34. Dette ligger forøvrig også i det vern tinglige bruksrettigheter har gjennom Grunnloven $\S 105$ og Den europeiske menneskerettighetskonvensjon protokoll 1 art. 1. 
For øvrig er det å håpe at Norge og Sverige, som har velutviklede rettssystemer og begge har høstet anerkjennelse som internasjonale fredsforhandlere, snart er i stand til å fremforhandle en ny beitekonvensjon for deres eget urfolk, framfor å belaste domstolen med tidkrevende og konfliktskapende saker som vanskelig kan løses på en hensiktsmessig måte i en rettssal. 